\title{
Educating to Remember: The Public Use of Comics in Germany and Italy
}

\begin{abstract}
This article presents different public uses of comics to represent difficult pasts on the basis of four case studies: the National Socialist and GDR pasts in the German memory field, and the Fascist past and terrorist/Mafia massacres in the Italian memory field. The comparative analysis focuses on three factors of influence: the narratives and aesthetic forms culturally legitimized in the two national public memory spaces, the cultural frames which define a specific past, and the cultural paradigms of transnational comics. In the final analysis, the article contemplates not only the graphic representations of the past, but also the social actors (artists, publishers, political institutions, public intellectuals) involved in this process of collectively working memory, their symbolic and cultural resources, and their power relationships.
\end{abstract}

Keywords: comics, cultural memory, cultural trauma, field of cultural production

\section{Comics and national memory fields}

This article will focus on comics published from 1946 to 2017 that narrate and recount difficult pasts. As a case study, I will compare German and Italian comics dealing with the National Socialist dictatorship and the socialist dictatorship in the German Democratic Republic (GDR) on one hand, and the Fascist dictatorship and the terrorist/Mafia massacres in Italy on the other. The main goal of this comparison is to understand how the narrative structure of comics is used to strengthen or contest social constructions of a past. Indeed, by spatializing and combining images and texts, comics possess great creative potential (e.g. Maggio 2007; Chute 2008) for communicating values and meanings about a past. In Bourdieusian terms, we can argue that their visual language makes it possible for them to shape a "space of possibles" (Bourdieu 1993): a space of possible narratives about difficult pasts which pursue a structure of meanings alternative to those included in the dominant master narratives. Yet the way in which this space of possibles is actualized depends on the agents involved in the memory struggle to define the "correct" representation of a given past. The more a remembering community is crossed by internal symbolic and social boundaries, the more the potential for conflict increases. This also concerns national collectivities. Indeed, despite recent globalization processes having led to transnational forms 
of memory (e.g. Huyssen 2003) and having undermined the symbolic power of nation states, the cultural production of national pasts is still fertile.

At this point, it is helpful to define memory for the purposes of this analysis. The increasing number of studies on memory in several (inter)disciplinary fields has led to a proliferation of definitions - for example, collective memory (Halbwachs 1925), cultural and communicative memory (Assmann 1999), and social memory (Namer 2000) - and perspectives (functionalism, constructivism, post-structuralism, postmodernism, deconstructionism, semiotics, and so on). For the purposes of this article, however, I will adopt three main frameworks for analyzing memory questions and their related problems.

The first framework concerns empirical investigations that focus on how collective memories are constructed through performative acts. Post-colonialist thought, in particular, influenced the concept of the "struggle for memory" as a "struggle for identity recognition" carried out by minority communities (Huyssen 1995; Edkins 2003). This gives rise to two puzzling questions that should be highlighted. The first concerns generalizing the outputs of a singular case study without dehistoricizing it. The second concerns the fact that struggles for memory are often understood in dichotomous terms, that is, in terms of dominant vs. minority groups. This prevents the identification of both the whole social structure involved in these collective conflictual memory processes and other ways of acting upon memory beyond resisting or exercising power (e.g. Rothberg 2009).

The second framework regards the classical sociological concept of memory as produced by collective groups which share a same time-space frame and interact with each other in order to construct a social framework of memory and make sense of their present conditions (Halbwachs 1925). More recently, to overcome the boundaries of local collective groups, scholars have adopted either a network or a systematic perspective. According to the network paradigm, memory processes are understood as the "free circulation of flows of narratives and ideas." However, little attention is paid to how local social and symbolic structures influence the reception of (global or globalized) past narratives and representations. According to Luhmann's system theory (1997), memory acts as a binary code composed of two exclusive processes: remembering and forgetting. The local dimension is embodied in the theory through the idea that the binary memory code of a social system selects the elements of the environment which should be incorporated in the system in order to enable its autopoiesis. This explanation also accounts for the capacity of the media to both archive past representations and create a sort of "amnesia” about a past. In other words, a systemic perspective on memory makes it possible to explain some basic mechanisms in the production and dissemination of the content and forms of memory. However, it is difficult to understand 
the roles agents play and how they try to legitimate past narratives through their social actions and cultural practices.

Finally, according to a semiotic framework, memory is a cultural text composed of a symbolic and temporal stratification of meanings (e. g. Erll 2010). Nevertheless, this perspective often excludes the broader cultural processes which co-define a socio-historical context, often reducing it to a merely historical background.

Following Bourdieu's concept of field (2002), for this article I propose a metalevel perspective according to which past discourses and narratives not only circulate over symbolic and social (national) boundaries, but are taken over by local social groups that use them differently depending on their cultural, economic, and social resources and the social and cognitive constraints of their sociocultural contexts. This means that the contents of memory that are characterized by transnational values and/or expressed by transnational symbolic forms (like graffiti) are given new symbolism according to the specific framework which governs the field where they are received (Grüning 2016). This also allows us to assume that some similarities exist between the social space defined by the power relationships of those who remember and the symbolic space defined by their narratives. In other words, the stance taken by the actors involved in the memory process is influenced by the hierarchical system and evaluation criteria which structure the field. Furthermore, not only past narratives on one past are ranked according to the dominant (aesthetic, ethical, scientific) criteria ruling the field, but also past events occupy different levels of legitimation. By referring to a nation state, it becomes crucial to understand the role of institutions in defining and legitimating specific past representations and hierarchies in public spaces. It is also sensible to consider how artistic expressive forms are selected to narrate past events according to the position these forms occupy in the corresponding field of cultural production. Thus, with respect to our case study, the question is whether and how comics represent a legitimate way to narrate difficult pasts in both the memory and literary fields.

For this analysis, I will consider the possible influence of two transnational processes which have transformed the study of memory in literary and cultural forms since the 1980s. The first one concerns the rise of traumatic memory related to the increased importance of Holocaust narratives. Traumatic memory narratives express universal values because they deal with biographical traumatic experiences, focus on victims (juxtaposed with perpetrators), and overcome local cultural boundaries thanks to the media (Levy and Sznaider 2006; Rothberg 2009). The second one concerns the progressive cultural and symbolic legitimation of comics in narrating traumatic pasts (Dauber 2006; Buhle 2007; Chapman, Ellin, and Sherif 2015). Crucial in this shift from "low" to "high" culture was the 
intellectual legitimation of Maus (Chute 2006; Kohli 2012). In this respect, the format of graphic novels and trauma narratives has been fundamental to legitimating comics as literature. Thus, in the following sections, I will try to illustrate how these two changes have been received in Italy and Germany and influenced the production of national comics about difficult pasts.

\section{Italian comics: Between ritualized and standardized memory}

From the post-war period until the end of the First Italian Republic (1992), Italy's public space was dominated by an anti-Fascist memory (De Bernardi and Ferrari 2004). This kind of memory was not only supported by political discourses, especially those of the radical left parties, but it was also reinforced by the prolific production of anti-Fascist novels, films, songs, and even comics. Serial comic books such as Pam il Partigiano (1946) and Il pioniere (1949-1964), or the anti-Fascist stories published in the weekly journal La Lotta (in 1951) and in the comic magazine Intrepido (five stories before 1950), were paradigmatic of how the image of the partisan as a Romantic hero played an educational role for children. The 1970s brought about three important changes: first, short narrative comics about the Italian Resistance were still published on the occasion of commemorative events (e.g. Liberation Day on 25 April); second, they were no longer drawn in politicized magazines for young people; and third, their graphic style was more accurate, as seen in Quest'uomo deve morire, drawn by Alfredo Castelli (1973), now considered one of the most important Italian authors of serial comics. In any case, the anti-Fascist system of values and the educational framework remained dominant. In the 1980s, a further step was taken towards the normalization of the "anti-Fascist memory," represented by the comic book La storia d'Italia, edited in its multiple volumes by the well-known Italian journalist Enzo Biagi (1996). Despite only some scenes in the third volume being devoted to the Italian Resistance, the fact that anti-Fascist memory is included in a homogeneous school narrative aimed at young people and intended to strengthen civic national identity is meaningful.

The fall of the existing three-party political system in the early nineties suddenly put the legacy of the anti-Fascist memory constructed over decades into question. The frequent objections to Liberation Day as an anti-Fascist celebration and the several (auto)biographical works where partisans were denounced for their violent acts against "normal citizens" are symbolic not only of the new political climate but also of the sudden changes to the collective memory framework. 
Indeed, the historical revision of the Italian Resistance was not accompanied by critical memory work but stressed the current conflicts in the political arena. However, in the last decade (always on commemorative occasions), we can detect a new wave of comics inspired by the anti-Fascist culture mainly supported by (local) civic political associations and institutions: Eroe partigiano (Della Santa 2010); I figli della schifosa (Pagliaro 2012); Storia della resistenza in Valsesia (Perrone and Perrone 2012), backed by the Institute of Italian Resistance in Piedmont; L'inverno di Diego (Baldazzini 2014); Bandierine: Tutta una storia di resistenze (Gallo and Pettinato 2015); Anita (Vasirani, Pomes, and Ronda 2015-2016), backed by the National Association of Italian Partisans (ANPI); and Pian d'albero (Putignano 2017), backed by the Historical Institute of the Resistance in Tuscany (ISRT). In most of the comics, the Resistance is narrated in a mimetic style. Even if the stories are less ideologized and the heroes more humanized than in the 1950s and 1960s, the graphic form and spatialization are still plain. Finally, it is difficult to find new issues diverging from a moralized "anti-Fascist paradigm," as is the case with In Italia sono tutti maschi (De Santis and Colaone 2008), devoted to the conditions of homosexuals under the Fascist regime, or L'inverno d'Italia (Toffolo 2017), which describes the Italian deportation of Roma communities. In general, we can argue that, even in this last phase, the comics remembering the Fascist regime were little influenced by the increasing interest in traumatic pasts since the 1990s. How might we explain this?

In the 1990s, mass media began to bring attention to the political, traumatic, and violent events of recent Italian history. These past events seem to be more suitable for exploring the protagonists' psychology and introducing innovative narrative devices by mixing historical and criminal elements, especially in film, TV series, and novels. Also, in the comic production of this era, there was a great deal of interest in dealing with Mafia- and terrorist-related events (e.g. the Bologna massacre in 1980, the massacre of Piazza della Loggia in 1974, the attacks on Giovanni Falcone and Paolo Borsellino), thanks to the initiative of Il becco giallo, a comic-book publisher concerned with imparting civic values (http:// main.beccogiallo.net [28 May 2019]). Thus, apart from a few exceptions (e.g. La giustizia siamo noi [Gabos and Cacucci 2010] and Quarant'anni adesso [Filippini 2016]) in which novels and films devoted to the same tragic past events are also made for entertainment purposes, comics which narrate recent Italian history share the main goal of educating by informing. Hence, following the continuous shift in Italian political culture from national to civic values, it seems that the increasing symbolic legitimation of graphic novels in recent decades has been mostly useful for renewing the educational role attributed to comics since the Fascist era (Zanatta, Zaghini, and Guzzetta 2009) rather than for exploring new graphical and aesthetic ways of representing past events. 
Summing up, in Italy after World War II, comics that narrate difficult past events were primarily educational, irrespective of the identity or social positions of the "moral entrepreneurs" of memory. Two circumstances support this observation. First, from the Fascist period until the sixties, comics were exclusively intended for children and young people. Therefore, the morality of their content was to be controlled. The role of moral controller has been performed by the state for a long time. Second, despite the existence of comics produced for an adult audience since the 1960s, those comics were mostly erotic in their content until the 1980s. Thus, comic magazines for children (e.g. the Corriere dei piccoli, the Corriere dei ragazzi, Tiramolla, Topolino, or the Catholic comics in Il Giornalino) maintained a dominant position in the field of comic production for a long time, filling a moral role. Nowadays, with the success of graphic novels, the target audience of comics dealing with difficult histories is wider (also including adults). However, since these comics remain influenced by their original educational function, and unlike other mass-market products such as films and novels, artistic values continue to be neglected.

\section{Germany: Overcoming two negative pasts}

In Germany, the use of comics for narrating the past has gained a foothold in the public sphere only in recent decades. The explanation for this is twofold. First, despite Germany's long tradition of illustrators and caricaturists, the genesis of an autonomous subfield of comic production here is more recent than in Italy. As a matter of fact, this tradition was interrupted during the Nazi regime, whereas in Italy comics played an important educational role even during Fascism. Furthermore, after World War II, comics were mostly imported from America, and they were generally classified as a mass-market product incorporating low cultural values (e. g. Jovanovic and Koch 1999; Sistig 2002). Second, in West Germany, until the fall of the Wall, a "positive memory" such as that of Italian anti-Fascism/resistance did not exist. By contrast, from the end of World War II to the Sessantotto movement in 1968 there was an elitist and critical intellectual class which influenced public opinion with discourses on the past orbiting around questions about German identity, democracy, and guilt (Müller 2000). On the other hand, everyday life was dominated by a culture of silence, with mass media and political narratives presenting a mitigated, ahistorical image of the Heimat. In the 1960s, a new sensibility towards the past emerged, as is highlighted by the progressive transformation of the Nazi camps into places of political education. However, only at the end of the 1970s, when the American TV series Holocaust was transmitted in Germany, 
did mass-media production begin to be an acceptable way to remember the negative German past (e.g. Cornelißen and Klinkhammer 2004). Thus, since the 1980s, two forms of memory were developed, both aimed at transmitting universal values: the first one, marked by a "trauma paradigm," was dominant in the broader field of cultural production and focused on individual and family biographies (e. g. Reitz's Heimat trilogy); the second one was based on an institutionalized idea of historical responsibility (Habermas 1988) dominating the intellectual public sphere.

After German reunification, the new political situation also conditioned the hierarchy of German collective memories. However, the new social context was characterized by a highly conflictual political climate depending on the reunification processes themselves, which exacerbated the economic, social, and cultural differences between East and West Germany. As a result, public memory work on the GDR past rapidly defined a conflictual field mirroring the reciprocal diffidence of East and West Germans. This field was dominated by media and political-institutional interpretations and master narratives of the GDR past, causing the marginalization and delegitimization of other forms of remembering and past narratives, from (n)ostalgic museums to festivals and novels, mainly carried out by East German actors.

The first consequence of this new interest in the GDR past was a decline in the importance of narratives related to the Nazi past. If we look at comic production (with the exception of the satirical comic strips of Adolf: Die Nazi-Sau [Moers 1998, 1999, 2006], anticipating the spirit of the film Der Untergang [see e. g. Ashkenazi 2011]), the majority of graphic novels on the Nazi past appeared later than graphic novels on the GDR past. More generally, in Germany, graphic novels dealing with the traumatic experience of National Socialism took hold relatively late in the context of the international success of Holocaust comics (e.g. Weiner and Fallwell 2011), even if the educational intention of this genre (e. g. Palandt 2011) fitted with the new orientation of German public memory.

Comics on the Nazi past include a varied palette of topics, from anti-Fascist stories like Das siebte Kreuz (Sharp [2015], adapted from the novel by the East German writer Anna Seghers); to stories on (individual) German opponents of the regime, like Sophie Scholl (Sabisch and Lünsedt 2015) and Bonhoeffer (Stetter 2010); to stories with Jewish protagonists, such as Die Suche (Naumann and Heuvel 2010); to family memory, such as Irmina (Yelin 2014). In any case, more than highlighting a new interest in narrating the Nazi past through comics, this variety of topics points to the absence of strong master narratives on this past, probably due to the difficulty of reconciling the paradigm of cultural trauma with the fact of bearing a national collective responsibility for that trauma.

By contrast, this difficulty never existed for the GDR past. Rather, the fear of sweetening the bitter pill of the Socialist state by using the visual language 
of comics (Grüning 2016) probably explains why writing and publishing comics on the GDR is mainly conceived as an institutional task which also involves the collaboration of historians and journalists. In recent decades, the institutional character of comics dealing with the GDR past has mostly been evident during commemorative events, such as the twentieth and twenty-fifth anniversaries of the fall of the Wall and the fiftieth anniversary of its construction. Indeed, for these occasions, comics on the GDR have been spatialized in commemorative places by redefining the memory landscape visually and cognitively ( $D a$ war mal was [Flix 2009] and Treibsand [Mönch, Lahl, and Kahane 2014] at the Berlin Wall Memorial, Grenzfall at the Zionskirche [Ulrich and Henseler 2011], Tunnel 57 in the Nordbahnhof [Henseler and Buddenberg 2012]).

If, on the one hand, this has led to new forms of remembering tragic events, on the other hand, the link created between sacred places and graphic novels restricts the possibilities of alternative legitimate ways of narrating this past by using the visual language of comics. Indeed, most of the comics which deal with the GDR past follow the same narrative structure of mass-media master narratives, based on the dichotomous scheme outlined in table 1.

Table 1: Criteria for classifying narratives on the GDR past.

\begin{tabular}{ll}
\hline DOCUMENTARY & FICTION \\
AUTHENTIC & UNREALISTIC \\
TRAUMA & (N)OSTALGIA \\
UNIVERSAL & LOCAL \\
LINEAR/COHERENT & NON-LINEAR/NOT COHERENT \\
\hline
\end{tabular}

The column on the left describes the legitimated way of narrating the GDR past. It can be said that most of the comics on the GDR - e. g. Drüben (Schwartz 2009), Da war mal was (Flix 2009), Grenzgebiete (Lenkova 2009), Grenzfall (Ulrich and Henseler 2011), Geteilte Stadt Berlin (Ulrich, Buddenberg, and Henseler 2012), Tunnel 57 (Henseler and Buddenberg 2012), 17 Juni (Lahl et al. 2013), Treibsand (Mönch, Lahl, and Kahane 2014), Herbst der Entscheidung (Hoffmnann and Linder 2014), and Madgermanes (Weyhe 2016) - present the following characteristics. (1) They tend to reproduce traces of authenticity (e.g. protocols of the GDR police and letters written by people who contested GDR politics). (2) They follow mimetic narrative criteria by preferring a linear and coherent narrative structure. (3) They reproduce the dominant topics of the GDR past, such as failed (or successful) attempts to escape from the GDR, the pervasive control of citizens' everyday life through surveillance, the paranoid ideological construction of social reality, and 


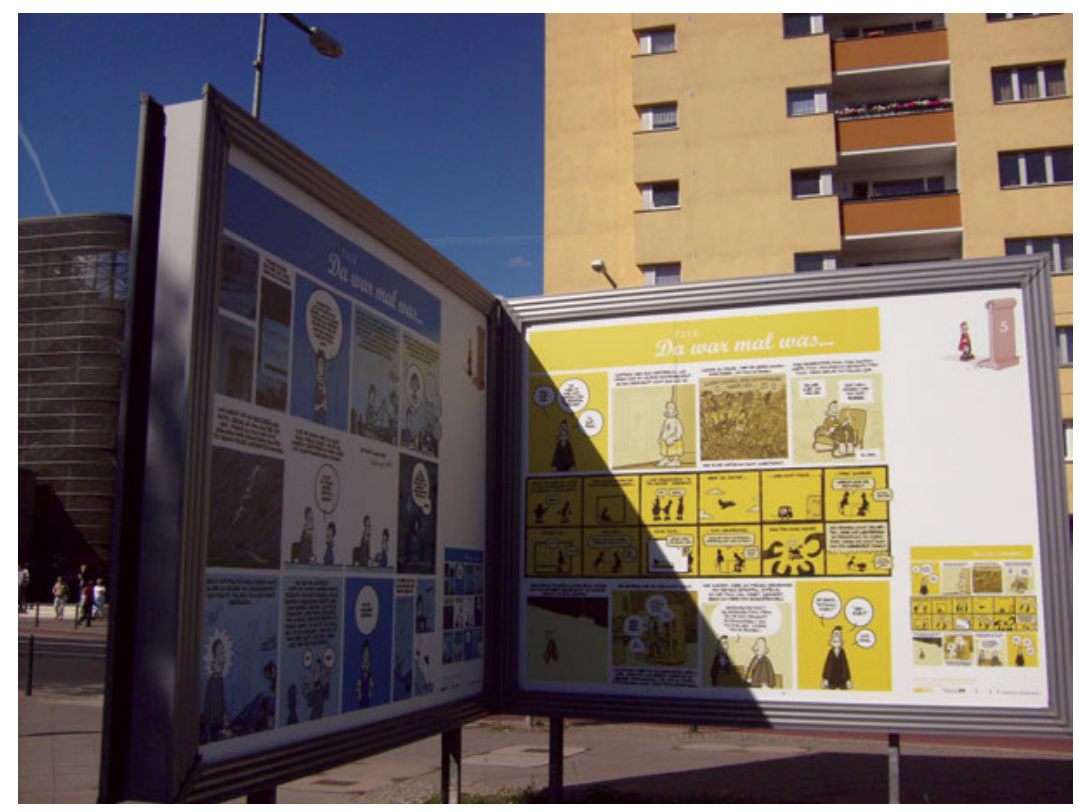

Fig. 1: Comics exhibition, Gedenkstätte Berliner Mauer, Berlin 2011.

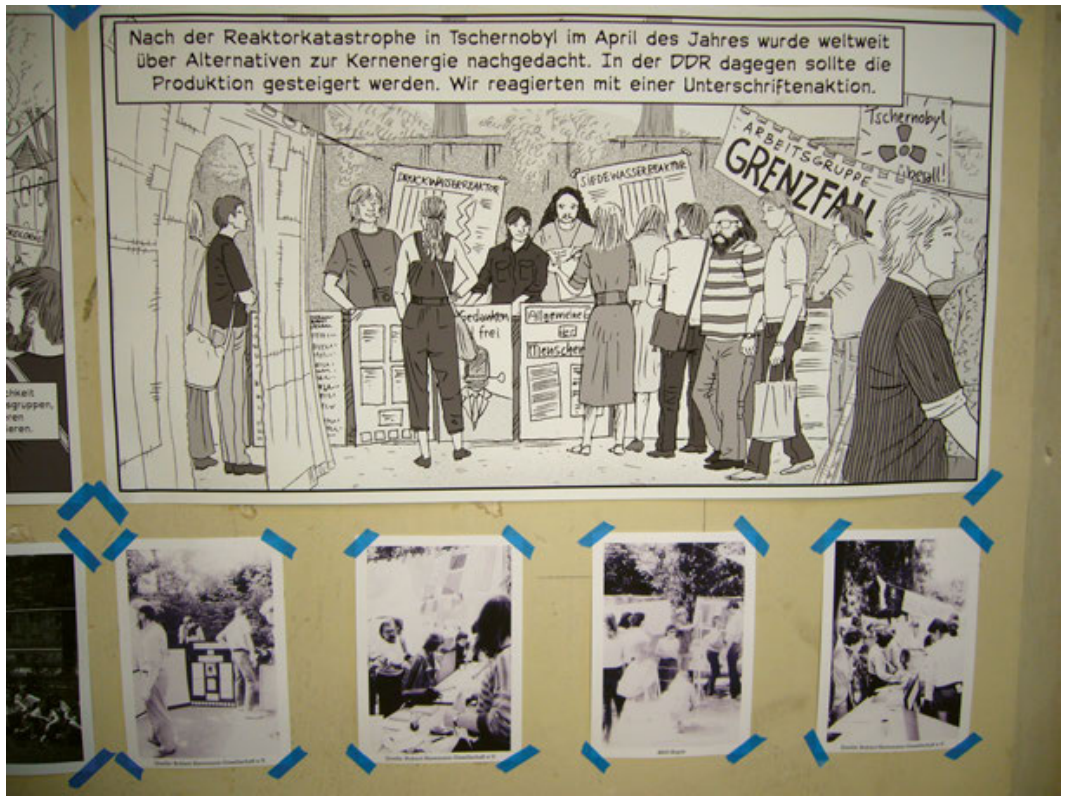

Fig. 2: Comics exhibition, Zionskirche, Berlin 2011. 


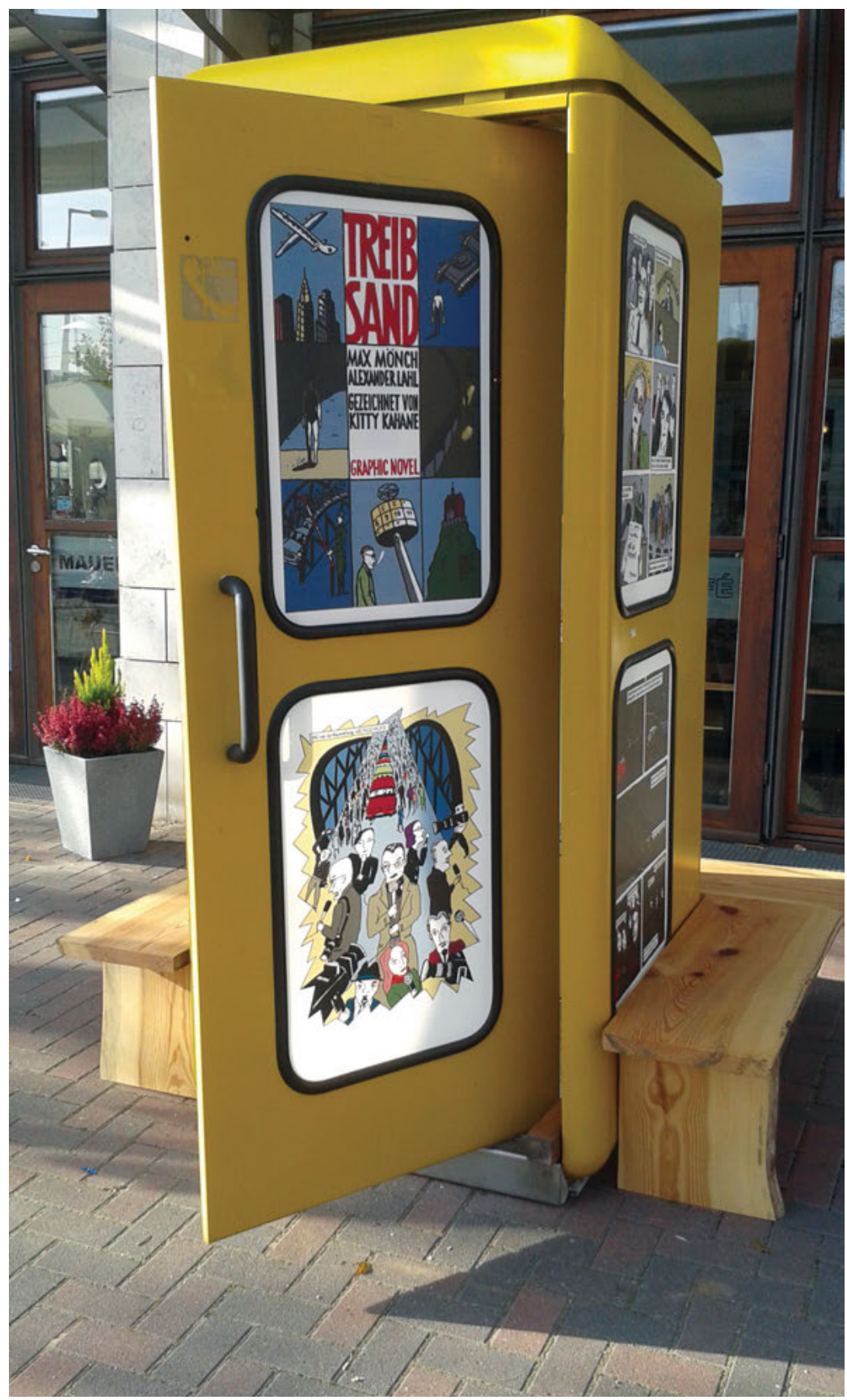

Fig. 3: Comics exhibition, Gedenkstätte Berliner Mauer, Berlin 2014. 
(dramatic) family conflicts during the peaceful demonstrations in the 1980s. In this regard, legitimated comic narratives are mostly used for teaching not only something about the GDR past, but also how to distinguish between a correct and a faulty way of remembering (e.g. Kutch 2016). By contrast, very few comics have proposed alternative ways of drawing and structuring stories about the GDR past which diverge from trauma narratives; those that do include Das UPgrade (Graupner and Wüstefeld 2012-2016) and Kinderland (Mawil 2014).

\section{Conclusions}

The analyses of comic narratives on difficult pasts in Germany and Italy have highlighted how their main function is to educate young people about the political and cultural values dominant in society at a given time. As a result, the expressive artistic potential of comics is rarely exploited because they are drawn according to heterodox criteria and goals. However, if we look at the genesis and transformation of both the memory and comics fields in the two countries, some crucial differences begin to emerge.

In Italy just after World War II, the hegemony of anti-Fascist memory (mainly supported by the Communist party) concerns also comics. After the crisis of Italy's First Republic, the anti-Fascist memory lost its supremacy, but comics grappling with the Fascist past continued to be produced mainly following the same narratives and values adopted in the past, although they now occupied a very marginal place in the comics field. This is partially due to the emergence of new narratives on the more recent past of terrorist and Mafia massacres, marked by the frame of cultural trauma. However, the fact that these comics are still oriented around a readership of young people makes their dominant educational purpose evident in this case as well.

In Germany, comics on GDR society dominate the subfield of comics covering past events. This is mainly due to two reasons. First, this second negative past contained a higher potential for conflict that was also continually expressed in the public sphere through other forms of cultural production (films, gadgets, docudramas, and so on). Second, as it belonged only to part of Germany's population, it was easier to use for traumatic narratives. By contrast, the possibility of narrating the Nazi past through comics according to the trauma paradigm is limited by the fact that, for this collective past, there still is a cultural taboo which has endured since the end of World War II. 


\section{Works cited}

Ashkenazi, Ofer. "Ridiculous Trauma: Comic Representations of the Nazi Past in Contemporary German Visual Culture." Cultural Critique 78 (2011): 88-118.

Assmann, Aleida. Erinnerungsräume: Formen und Wandlungen des kulturellen Gedächtnisses. Munich: Beck, 1999.

Baldazzini, Roberto. L'inverno di Diego: Le quattro stagioni della Resistenza. Bologna: thebox, 2014.

Biagi, Enzo. La storia d'Italia: 40 anni di Repubblica. Milan: Mondadori, 1996.

Bourdieu, Pierre. The Field of Cultural Production: Essays on Art and Literature. Cambridge: Polity Press, 1993.

Bourdieu, Pierre. "Les Conditions sociales de la circulation international des idées." Actes de la Recherche 145 (2002): 3-8.

Buhle, Paul. "History and Comics." Reviews in American History 35.2 (2007): 315-323.

Castelli, Alfredo. “Quest’uomo deve morire.” Corriere dei ragazzi 17 (29 April 1973): 44-51.

Chapman, Jane L., Dan Ellin, and Adam Sherif. Comics, the Holocaust and Hiroshima.

Basingstoke and New York: Palgrave, 2015.

Chute, Hillary. “'The Shadow of a Past Time': History and Graphic Representation in Maus.” Twentieth-Century Literature 52.2 (2006): 199-230.

Chute, Hilary. “Comics as Literature? Reading Graphic Narrative.” PMLA 123.2 (2008): 452-465.

Cornelißen, Christoph, and Lutz Klinkhammer, eds. Erinnerungskulturen. Frankfurt am Main: Fischer, 2004.

Dauber, Jeremy. “Tragic Stories: Will Eisner’s American Jewish History.” AJS Review 30.2 (2006): 277-304.

De Bernardi, Alberto, and Paolo Ferrari, eds. Antifascismo e identità europea. Rome: Carocci, 2004.

Della Santa, Francesco. Eroe Partigiano. Campi Bisenzio: NTE edizioni, 2011.

De Santis, Luca, and Sara Colaone. In Italia sono tutti maschi. Bologna: Kappa Edizioni, 2008.

Edkins, Jenny. Trauma and the Memory of Politics. Cambridge: Cambridge University Press, 2003.

Erll, Astrid. "Towards a Conceptual Foundation for Cultural Memory Studies." A Companion to Cultural Memory Studies. Ed. Erll and Ansgar Nünning. Berlin and New York: De Gruyter, 2010. 1-15.

Filippini, Sergio. Quarant'anni adesso: Un racconto negli anni settanta. Milan: Hazard Edizioni, 2016.

Flix. Da war mal was. Hamburg: Carlsen, 2009.

Gabos, Otto, and Pino Cacucci. La giustizia siamo noi. Milan: Rizzoli, 2010.

Gallo, Stefano, and Tuono Pettinato. Bandierine: Tutta una storia di resistenze. Gello: Barta, 2015.

Graupner, Ulrich, and Sascha Wüsterfeld. Das UPgrade. Berlin: GCM Go City Media, 2012-2016.

Grüning, Barbara. "Commemorating the Berlin Wall: Forms and Spaces of Collective Memory after the Cold War." Cold War Cities: History, Culture and Memory. Ed. Marjatta Hietala and Katya Pizzi. Oxford: Lang, 2016. 17-44.

Habermas, Jürgen. "Historical Consciousness and Post-Traditional Identity." Acta Sociologica 31.1 (1988): 3-13.

Halbwachs, Maurice. Les Cadres sociaux de la mémoire. Paris: Librairie Félix Alcan, 1925. 
Henseler, Thomas, and Susan Buddenberg. Tunnel 57. Berlin: Links-Verlag, 2012.

Hoffmann, Peter M., and Bernd Linder. Herbst der Entscheidung. Berlin: Links Verlag, 2014. Huyssen, Andreas. Twilight Memories. New York and London: Routledge, 1995.

Huyssen, Andreas. Present Pasts. Stanford: Stanford University Press, 2003.

Jovanovic, Goran, and Ulrich Koch. "Comics Debate in Germany: Against Dirt and Rubbish, Pictorial Idiotism, and Cultural Analphabetism.” Pulp Demons: International Dimensions of the Postwar Anti-Comics Campaign. Ed. John A. Lent. London: Fairleigh Dickinson University Press, 1999. 93-128.

Kohli, Puneet. "The Memory and Legacy of Trauma in Art Spiegelman's Maus.” The Journal of Historical Studies 1.1 (2012): 1-5.

Kutch, Lynn M., ed. Novel Perspectives on German-Language Comics Studies: History, Pedagogy, Theory. London: Lexington Books, 2016.

Lahl, Alexander, Tim Köhler, Max Mönch, and Kitti Kahane. 17. Juni. Dresden: Metrolit, 2013.

Lenkova, Claire. Grenzgebiete: Eine Kindheit zwischen Ost und West. Hildesheim: Gesternberg, 2009.

Levy, Daniel, and Natan Sznaider. The Holocaust and Memory in the Global Age. Philadelphia: Temple University Press, 2006.

Luhmann, Niklas. Die Gesellschaft der Gesellschaft. Frankfurt am Main: Suhrkamp, 1997.

Maggio, Jay. “Comics and Cartoons: A Democratic Art-Form." Political Science and Politics 40.2 (2007): 237-239.

Mawil. Kinderland. Berlin: Reprodukt, 2014.

Moers, Walter. Adolf: Äch bin wieder da!! Frankfurt am Main: Eichborn, 1998.

Moers, Walter. Adolf 2: ̈̈ch bin schon wieder da! Frankfurt am Main: Eichborn, 1999.

Moers, Walter. Adolf - Der Bonker: Eine Tragikomödie in drei Akten. Munich: Piper, 2006.

Mönch, Max, Alexander Lahl, and Kitti Kahane. Treibsand. Dresden: Metrolit, 2014.

Müller, Jan-Werner. Another Country: German Intellectuals, Unification and National Identity.

New Haven and London: Yale University Press, 2000.

Namer, Gérard. Halbwachs et la mémoire sociale. Paris: Harmattan, 2000.

Naumann, Britta, and Eric Heuvel. Die Suche. Brunswick: Schroedel, 2010.

Pagliaro, Alberto. I figli della schifosa. Milan and Turin: Edizioni BD, 2012.

Palandt, Ralf, ed. Rechtsextremismus, Rassismus und Antisemitismus in Comics. Berlin: Archiv der Jugendkulturenverlag, 2011.

Perrone, Giorgio, and Luca Perrone. Storia della resistenza in Valsesia. Biella-Vercelli: Istituto storia della resistenza, 2012.

Putignano, Pierpaolo. Pian D'albero. Scarperia: Kleiner Flug, 2017.

Rothberg, Michael. Multidirectional Memory. Stanford: Stanford University Press, 2009.

Sabisch, Ingrid, and Heiner Lünsedt. Sophie Scholl. Munich: Knesebeck, 2015.

Schwartz, Simon. Drüben. Berlin: Avant-Verlag, 2009.

Sharp, William. Das siebte Kreuz. Berlin: Aufbau Verlag, 2015.

Sistig, Joachim. Invasion aus der Vergangenheit. Frankfurt am Main: Lang, 2002.

Stetter, Moritz. Bonhoeffer. Gütersloh: Gütersloher Verlagshaus, 2010.

Toffolo, Davide. L'inverno d'Italia. Rome: Coconino Press, 2017.

Ulrich, Johann, and Thomas Henseler. Grenzfall. Berlin: Avant-Verlag, 2011.

Ulrich, Johann, Susanne Buddenberg, and Thomas Henseler. Geteilte Stadt Berlin. Berlin:

Avant-Verlag, 2012.

Vasirani, Valeria, Andrea Pomes, and Tommaso Ronda. “Anita”. nAnpi 4-9 (2015), 1-3 (2016): n. pag. 
Weiner, Robert. G., and Lynne Fallwell. "Sequential Art Narrative and the Holocaust." The

Routledge History of the Holocaust. Ed. Jonathan C. Friedman. New York: Routledge, 2011. 464-469.

Weyhe, Birgit. Madgermanes. Berlin: Avant-Verlag, 2016.

Yelin, Barbara. Irmina. Berlin: Reprodukt, 2014.

Zanatta, Sara, Samanta Zaghini, and Eleonora Guzzetta. Le donne nel fumetto. Latina: Tunué, 2009.

Dr Barbara Grüning is assistant professor of Sociology at the University of Milan Bicocca. From 2013 to 2017, she was a research associate on the EU project "International Cooperation in the Social Sciences and Humanities" (Interco-SSH). She has been a visiting researcher at the Zentrum für Zeithistorische Forschung (ZZF) in Potsdam, the University of Lüneburg (DAAD postdoc grant), the Technische Universität Berlin, and the Zentrum Marc Bloch, Humboldt Universität zu Berlin. Her research fields range from memory studies, space studies, and comics studies to the sociology of knowledge and the sociology of intellectuals. Her publications include "Transition, Memory and Narrations in the Urban Space: The Case of East German Cities" (2010), "The Art of Narrating and the Question of Cultural Acknowledgment: The Case of 'Die Kinder von Golzow' and a Reunified Germany” (2011), "Narrating the Cities in Comics: The Case of Bologna" (2011), "Kommerzielle (N) Ostalgie als Vergessensform” (2012), "Living Public Spaces: New Forms of Collective Experience of a Generation "without future"” (2012), "Commemorating the Berlin Wall: Forms and Spaces of Collective Memory after the Cold War" (2016), and "Beyond the Cold War? The Reception of Arendt in Germany and Italy" (2017). 